Behavior and Social Issues, 16, 65-88 (2007). (C) Lyle K. Grant. Readers of this article may copy it without the copyright owner's permission, if the author and publisher are acknowledged in the copy and the copy is used for educational, not-for-profit purposes.

\title{
Peak Oil as a Behavioral Problem
}

\author{
Lyle K. Grant \\ Athabasca University
}

\begin{abstract}
Peak oil is the point at which oil production reaches a maximum value and thereafter declines. Because of the dependence of industrialized society on oil, peak oil may be one of the most important, possibly cataclysmic, events in modern history. Averting economic damage due to peak oil is defined as a behavioral problem requiring avoidance responding as a solution. Factors that impede successful avoidance responding are examined. A risk management approach for addressing the problem is advocated.

KEYWORDS: Peak oil, avoidance behavior, behavioral momentum, fossil fuel consumption, risk management

Peak oil is the point at which oil production reaches a maximum yearly value and declines afterward due to the depletion of oil. The peak of oil production in the United States, for example, was reached on a calendar-year basis in 1971, when annual oil production was about 3.5 billion barrels (Energy Information Administration, 2006b). Since 1971 U.S. oil production has declined steadily, reaching 1.87 billion barrels per year in 2005. Worldwide discoveries of oil peaked in the mid-1960's and have been declining since that time (Energy Bulletin, 2006b). For the past several years there has been a focus on the possibility that worldwide oil production will peak and several authors have considered this potential event and its implications (e.g., Campbell, 1988; Deffeyes, 2005; Goodstein, 2004; Heinberg, 2003, 2004; Klare, 2004; Kunstler, 2005; Leggett, 2005; Tertzakian, 2006).

Reaching a peak in worldwide oil production has been largely discussed as a geological, economic, and political event. Missing from much of this discussion are behavioral aspects of peak oil. In the present paper I examine peak oil as a behavioral problem. At the outset the nature of peak oil is discussed, followed by a review of the projected date of the peak and the social and economic consequences of reaching a peak. Behavioral aspects of peak oil are then discussed, especially the challenges involved in responding effectively to a projected peak-oil future. The use of risk management is discussed as a means of addressing the problem.
\end{abstract}

\section{What is The Nature of Peak Oil?}

Discussions of oil scarcity are often couched in terms of the notion that we may be "running out of oil." When a national peak in oil production is reached, it does not mean a country is exhausting its oil supply. A production peak is typically reached only when about half of the total reserves of oil have been extracted (Hirsch, Bezdek, \& Wendling, 
2005). A country that has reached the peak oil point can still continue producing oil for many years, though at a progressively declining rate.

The point at which a country completely runs out of oil is relatively unimportant. By the time a culture or nation has entirely exhausted a nonrenewable commodity like oil, the supply of the commodity is so small the group has already adapted to the scarcity, for example by using substitutes, decreasing their standard of living or even by reducing the population. In contrast, peak oil is important because it is the point at which oil supply growth ceases and begins to shrink after a long history of continuing increases and in the face of rising demand. Therefore, unless a decrease in demand can be timed appropriately, peak oil is expected to produce a substantial imbalance between oil supply and demand. This problem is compounded because supply-demand imbalances in natural gas, a partial substitute for oil, appear increasingly likely in some areas of the world such as North America (Hughes, 2006).

\section{When Will Oil PeAK?}

Expert estimates of the date of worldwide peak oil range widely. Kenneth Deffeyes (2006), a former Shell Oil geologist, stated the peak already occurred in late 2005. Campbell and Laherrère (1998) predicted a peak during the 2001-2010 decade. In contrast, oil optimists claim they are unable to predict any peak in production because oil is so abundant (Hirsch et al., 2005). One of the more optimistic outlooks is that of Abdallah S. Jum'ah, the Chief Executive Officer of Saudi Aramco, the state oil company of Saudi Arabia. He places remaining world oil reserves at 4.7 trillion barrels, enough to provide the world with its current level of supply for the next 140 years (Lundberg, 2006b).

World oil reserves are largely owned by national governments, many of which are secretive about field-by-field production and oil reserve data. This secrecy compounds the formidable technical problems in estimating the reserves in any oil field, leaving us with incomplete and unaudited information about total world oil reserves (Simmons, 2005b). Within OPEC (Organization of Petroleum Exporting Countries), production quotas have been set based on a percentage of a country's reserves. Under this system, the higher a country sets its level of reserves, the more it is officially allowed to produce, and the greater the income it receives from oil sales. High reserve estimates are therefore differentially reinforced. During the period from 1985 to 1990, several OPEC countries boosted their reserves, and it is suspected these increases led other OPEC countries to do likewise. Because there were no discoveries of new major oil fields reported in these countries during this time, some have concluded that at least a substantial part of the reported increases in reserves was a political event that permitted production quotas to rise (Campbell, 1988).

A pivotal historical figure in peak oil forecasting was M. King Hubbert, a Shell oil geologist who, in 1956, correctly predicted the peak in oil production in the lower 48 states would be reached in about 1970 (Deffeyes, 2005). His original prediction was widely discounted at the time he made it as well as for many years afterward. Even in the 
late 1960's, just prior to the peak, oil production in the U. S. increased annually as it had for decades, leading many people to believe this well established trend would continue. During the 1960's the U. S. Geological Survey, for example, predicted that a peak in U.S. production would occur in the year 2000 (Blanchard, 2005), 30 years beyond the actual date. Hubbert's basic method was to use annual additions to oil reserves and cumulative oil production to extrapolate the total reserves and the date at which peak production would be reached, at the halfway point of total cumulative production. [See Deffeyes (2005) for a step-by-step explanation of Hubbert's predictive system.]

Hubbert applied his predictive methods to worldwide oil production and calculated this peak would occur in the year 2000, according to the most optimistic of two scenarios (Deffeyes, 2005). World oil production however did not peak in the year 2000, so Hubbert's prediction is incorrect by at least several years. Heinberg (2003) has attributed this inaccuracy to incomplete data Hubbert worked with, as well as minor flaws in his methods. Due to these problems, Hubbert's prediction was likely off by only ten years, according to Heinberg.

Chris Skrebowski (2006), editor of the Petroleum Review, has approached the problem of predicting peak oil by doing a field-by-field analysis of oil flows and has calculated that a peak in production will occur in 2010-2011 at 92 to 94 million barrels per day. He pointed out there is a widening gap between oil discoveries, which are falling, and oil demand, which is increasing. For roughly the last 20 years, oil discoveries (i.e., additions to oil reserves) have fallen short of oil consumption (Hirsch et al., 2005).

There are increasing expressions of concern in the media that oil may be close to peak production. Robert Semple (2006), an Associate Editor on the The New York Times' editorial board, published an op-ed piece stating the concept of peak oil is "almost certainly correct." Campbell and Laherrère (1998) published an article in the Scientific American describing the fundamental concepts of peak oil. Former President Clinton (2006, ๆ 11) acknowledged "We may be at a point of peak oil production." Former Vice President Gore indicated we are "almost certainly are at or near what they call peak oil" (Energy Bulletin, 2006a, ๆ 5). Newsweek economic columnist Jane Bryant Quinn (2006) indicated that rates of oil production may soon decline and called for an emphatic response:

To protect ourselves and our economy, the order of business should be: sound a national call for conservation, invest heavily in energy efficiency, drill for any oil we've got and embark on crash programs (with tax incentives) to manufacture petroleum alternatives on a large scale. (p. 5)

Howard (2006) has empirically documented increases in media attention to peak oil, but also found that overall media interest in the topic remains at a relatively low level.

Countering the arguments of advocates of impending peak oil are the oil optimists, who are sometimes called the oil cornucopians. The optimists believe the peak in oil production is not near, there have been many incorrect predictions of faltering oil supplies in the past, and modern oil drilling and recovery technologies will ensure the continuing availability of oil supplies for many decades. For example, in congressional 
testimony Robert Esser (2005, ๆ 3) of Cambridge Energy Research Associates stated: "Rather than an imminent 'peak,' [of oil production] we envision an 'undulating plateau' two to four decades away." Elsewhere, Esser has described peak oil theory as "garbage" (Andrews, 2006, ๆ 2). Similarly, the Exxon-Mobil corporation envisions no imminent oil production peak, and includes the following observations in an advertisement:

Will we soon reach a point when the world's oil supply begins to decline? Yes, according to so-called "peak oil" proponents. They theorize that, since new discoveries have not kept up with the pace of production in recent years, we will soon reach a point when oil production starts going downhill. So goes the theory.... The theory does not match reality, however. Oil is a finite resource, but because it is so incredibly large, a peak will not occur this year, next year or for decades to come. (Exxon-Mobil, 2006b, p. 1)

The Exxon-Mobil ad campaign has been controversial. Charles Maxwell, senior oil analyst at Weeden and Company, whom Barron's Magazine has called the "Dean of energy analysts" (Maxwell, 2004), reflected:

[the Exxon-Mobil ad campaign] verges on the irresponsible because it says to the government there is no problem. It says to the media there is no problem. It says to the public there is no problem. So we are now likely to march with fife and drum, banners flying, into the maw of destruction without so much as a sideways glance because Exxon tells us that the problem is resolved. (Ward, 2006, p. 43)

The divergence of opinion about future oil supplies might be reduced if there were a concerted program of oil production and reserve data reform. According to Houston investment banker Matthew Simmons (Motavalli, 2005; Simmons, 2005a), the existing field-by-field data concerning oil production and reserves is either poor or nonexistent, which makes it difficult to make future projections of oil supplies. Simmons has called for the United Nations, the International Monetary Fund, and national energy departments to cooperate in order to determine current oil reserves. He maintains 30 oil analysts could determine world oil reserves in 30 days if the proper data were made available to them (Wood, 2005). As it is, peak oil has often become a matter of speculation and guesswork with certain experts steadfastly maintaining their contradictory positions in the absence of clear data. The lack of consensus regarding the approximate date of peak oil is a factor that has led to inaction on the issue, as will be discussed later.

\section{What Will be the Effects of Peak Oil?}

No important nonrenewable natural resource such as petroleum has ever before peaked in its worldwide supply. This lack of any precedents makes it difficult to predict the specific adverse effects of peaking and how they might be addressed. A study known as the Hirsch Report (Hirsch et al., 2005), commissioned by the U.S. Department of Energy to assess the risks of peak oil, predicted that peaking would cause a severe 
problem in transportation fuels and higher oil prices that would cause world economic hardship. Hirsch et al. describe peak oil in ominous terms:

The world has never faced a problem like this. Without massive mitigation more than a decade before the fact, the problem will be pervasive and will not be temporary. Previous energy transitions (wood to coal and coal to oil) were gradual and evolutionary; oil peaking will be abrupt and revolutionary. (p. 64)

Hirsch et al. (2005) concluded that these effects of peak oil could be lessened to some extent but only through an expensive government-sponsored crash or mitigation program. They identified three scenarios, one in which the crash program began at the time of peak oil, and two other scenarios in which the program began 10 or 20 years in advance of the oil peak. Hirsch and his colleagues were relatively optimistic about the success of a program to stem the effects of peak oil, but only if one of their two advance crash programs were pursued, preferably the 20-year program. Hirsch and his colleagues did not specify a likely peak year, but instead cited oil industry experts who identified the peak year as occurring within a wide range, from 2006-2007 to 2025 and beyond. In a 2006 report, Hirsch is said to have guessed peak oil will occur within 5 to 10 years (Bloomberg, 2006). The complexities of peak oil, especially with the vagueness of the crucial oil production and reserve data, make definitive conclusions difficult. Hirsch has summarized this by saying "The reality is, this thing is extremely complicated. My honest view is that anybody who tells you that they have a clear picture probably doesn't understand the problem" (Crensen, 2005, ๆ 42).

Hirsch et al.'s (2005) mitigation program included conserving energy, improving energy efficiency, improving recovery of oil in the ground, developing heavy oil and oil sands, turning natural gas into liquid fuels, turning coal, oil shale, and various types of plant matter (biomass) into liquid fuels, developing hydrogen as a transportation fuel, and switching many liquid-fuel uses to electricity.

The Hirsch report has been criticized among those concerned with peak oil because it narrowly defines the issue as a liquid-fuels problem in which an implicit goal is to maintain many existing energy-use practices without any attention to the effect this has on global warming (Hopkins, 2006a). Many who have written about the problem of peak oil have expressed equal concern with the issue of global warming (e.g., Goodstein, 2004; Leggett, 2005). If oil production does peak, there will likely be considerable pressure to make use of energy substitutes such as coal (e.g., to power electric and hybrid vehicles and as a feedstock for conversion into diesel fuel). The increased burning of coal and the process of coal-to-liquids conversions have the potential to increase air and water pollution as well as exacerbate climate change (Leggett, 2005; Pfeiffer, 2004). Therefore, a potential effect of peak oil is increased environmental damage and more rapid climate change.

Heinberg $(2003,2004)$ and Kunstler (2005) have discussed problems with each of the Hirsch Report's alternatives for producing liquid fuels, and as a result are more pessimistic concerning the success of a crash program. For example, ethanol manufactured from grains is currently being subsidized in the U. S. to promote it as an 
alternative to oil, but the net energy balance of ethanol remains controversial (Institute of Science in Society, 2006). There is also not enough agricultural land in the U. S. to replace its current oil consumption with ethanol production (Heinberg, 2003). Brown (2007) calculated that if all the grain crops of the U. S. were converted to ethanol, this would meet only $16 \%$ of U. S. vehicle fuel demand. He suggests that increased use of cropland for ethanol production will steadily displace food production and increase world food prices, creating hardships for the two billion people who spend half or more of their income on food. One 25-gallon tank of ethanol fuel is made from enough grain to feed one person for an entire year (Brown, 2007). Production of palm oil, which is also used as a biofuel, is currently creating a large range of environmental problems due to the clearing of rain forests in Southeast Asia (Brown \& Jacobson, 2005; Cohen, 2007).

Oil and natural gas are not only fuel sources but are also the basis for fertilizers, pesticides used in large-scale food production, plastics and petrochemicals. As Leggett $(2006,9)$ observed:

We have allowed oil to become vital to virtually everything we do. Ninety per cent of all our transportation, whether by land, air or sea, is fuelled by oil. Ninety-five per cent of all goods in shops involve the use of oil. Ninety-five per cent of all our food products require oil use. Just to farm a single cow and deliver it to market requires six barrels of oil, enough to drive a car from New York to Los Angeles.

Fossil-fuel recovery, processing and use are a set of interlocking practices (Glenn, 1991) that are woven tightly into the agricultural and manufacturing infrastructure of modern society. Scarcity of oil may therefore lead to major problems in the production and distribution of food and essential consumer goods. In the aftermath of peak oil, Kunstler (2005) for example envisions a worldwide die-off in which millions of people perish from hunger and chaos reigns. Klare (2004) anticipates a period of warfare in which the largest consumer of oil, the U. S., seeks to use military force to capture sources of foreign oil in a context of declining oil supply. Phillips (2006), among many others, has made the case that oil supply motivated the U. S. invasion of Iraq in 2003.

Catton (1982) has approached the phenomenon of peak oil from a broader conceptual perspective, in terms of the concept of overshooting of global carrying capacity. Catton's key thesis is the carrying capacity of the human species on earth has been temporarily increased by the availability of the concentrated energy in fossil fuels. Once these fuels begin to diminish, the carrying capacity of the planet, its ability to support human life on the scale that exists today, will decline as well. During the $18^{\text {th }}$ and $19^{\text {th }}$ centuries the earth's population increased 1.4 and 1.9 times (U. S. Census Bureau, 2006a), respectively, but during the $20^{\text {th }}$ century, when fossil fuels began to be massively extracted using mechanized technology, the population increased from 1.6 to 6.1 billion people (U. S. Census Bureau, 2006b), an increase of 3.8 times. These statistics suggest that fossil-fuel-fed changes in technology have multiplied the earth's population, possibly beyond a factor that is sustainable without the use of such fuels.

Due to the unprecedented nature of a worldwide peak of any key energy commodity, it is difficult to predict the extent of a future peak-oil crisis. Pessimists portray a dark 
future in which the human population will shrink due to famines, whereas relative optimists maintain the crisis can be managed, especially with advance planning. The optimists point to the example of Cuba, which rapidly lost most of its oil supply and $80 \%$ of its export market after the collapse of the Soviet Union (McBay, 2005; Quinn, 2004). Cuba was able to survive without catastrophic consequences, though per capita caloric intake initially dropped by one third. Cuba managed the crisis through a series of programs that included increasing bicycle use, replacing tractors with oxen, planting urban food crops, replacing petrochemical-based pesticides with natural alternatives, and channeling resources to essential services like medical care. Other measures included encouraging tourism, inviting foreign companies to invest in the country on favorable terms, and legalizing certain forms of self-employment (Córdova, 1996). Cuba's ability to overcome this crisis is especially noteworthy because it lost most of its oil supply very rapidly, unlike a typical peak-oil scenario in which the decline is more gradual. The fact the optimists are showcasing contemporary Cuba as a success story is itself a sobering commentary on the scope of the potential problem.

\section{Behavioral Aspects of Peak OIL: Basic Contingencies}

In behavioral terms, peak oil is an aversive consequence. The Hirsch report's crash program (or some variant of it) is an avoidance response that will prevent the worst of the aversive consequence from occurring. Meeting the challenge of peak oil is therefore a problem of engaging in successful avoidance responding. Avoidance responding is such that an aversive or undesirable consequence occurs following inaction, or the failure to respond, and the Hirsch report casts the problem of peak oil in these terms. ${ }^{1}$

Peak oil is an especially difficult problem due to (a) the nonrecurring nature of peak oil, (b) the delay of the aversive consequence, (c) the variability in the predicted date of peak oil, (d) the predicted aversiveness of peak oil, and (e) the nature of avoidance responding.

\footnotetext{
${ }^{1}$ The problem of peak oil is described here as an instance of one-trial discriminated avoidance responding. Often contingencies of this type apply to the behavior of an individual subject, but in this case the contingency (i.e., if-then relationship between carrying out the crash program and avoiding a peak-oil crisis) applies to the behaviors of most of the people in the industrialized world that depend on oil energy. This cultural-level contingency is likely to function or fail to function in a more complex fashion than if it applied to the behavior of a single subject. For example, as a group contingency (Sulzbacher \& Houser, 1968), the policy initiatives of a subset of the population (i.e., a relatively small group of formal leaders and opinion leaders) can avoid or fail to avoid dire peak-oil consequences for the entire population. Moreover, energy recovery and use constitute a complex web of interlocking practices (Glenn, 1991) that include everything from routine daily family trips, the vehicle manufacturing industry, the government subsidization of streets and highways, etc. The effects of the interlocking nature of these practices are speculative and Mattaini (2006) has called for experiments to study them. Interlocking practices may be another deterrent to peak-oil avoidance behaviors, but in any case they make peak-oil avoidance a more complex process requiring sweeping cultural transition rather than individual behavior change.
} 


\section{Peak Oil as a Nonrecurring Consequence}

The once-in-history aspect of worldwide peak oil makes it necessary to discriminate the avoidance contingency in advance of the aversive consequence's occurrence and to do so without any previous learning trials. Addressing peak oil successfully prior to the peak itself can therefore be considered as an instance of one-trial discriminated avoidance responding. In one trial, it is necessary to discriminate (a) that peak oil will occur, (b) a plausible time frame in which peak oil will occur, (c) that peaking will be a serious problem, (d) that a crash program is capable of avoiding or lessening the problem, and (e) the time interval required for the crash program to have a mitigating effect before peaking occurs. It is of course also necessary to implement the crash program. This is a difficult assignment because each of the five elements of the discrimination is contested in contemporary discussions in varying degrees, and because the program itself is a major effort that appears to require both cultural reinvention and substantial spending. ${ }^{2}$

A major behavioral problem with peak oil is simply that nobody has had any practice in coping with such a unique event. One of the major contributions of successful applications of behavior analysis is to structure learning experiences so people are given lots of practice and feedback in acquiring and maintaining skills (e.g., Grant \& Evans, 1994; Martin \& Pear, 2003). With a once-in-history event like peak oil, no one has had prior opportunities to learn to behave successfully toward such an event.

Examples of nonrecurring, once-in-history events are by their very nature difficult to come by, but once-in-a-lifetime events of individuals provide some clues. As Catania (1998) has discussed, it is often difficult to induce people who have never had a car crash to wear vehicle safety belts in order to avoid injuries in a collision. It is difficult to get patients who have never suffered a heart attack to take medications or adopt a diet that will avoid one. Compliance with treatment is one of the major problems in medicine. The more frequently we encounter an event, the more practice and feedback we receive, and the more effective our behavior becomes (e.g., Alavosius \& Sulzer-Azaroff, 1990; Semb, 1974). As discussed earlier, there is considerable variation in peak-oil scenarios, which is likely due to the lack of practice people have had behaving in a peak-oil environment. The most similar past experience was provided by the oil shortage of 1973, when producers curtailed supply temporarily for political ends. As Goodstein (2004) has

\footnotetext{
${ }^{2}$ In this section I suggest that successful avoidance of the worst aspects of peak oil requires discrimination (i.e., identification) of five key features of the peak-oil problem. These discriminations, if successful in inducing a crash program, would be instances of a verbally regulated process often discussed under the rubric of rule-governed behavior. In rule-governed behavior (Skinner, 1969), a rule in the form of a specification of an if-then relationship between behavior and consequences (e.g., if a crash program is begun now and if oil peaks in 10 years, then we can avoid many of the harmful effects of peaking) can act to motivate and guide subsequent actions. Verbally regulated behavior is essential in responding effectively to consequences, like a peak-oil crisis, that are not subject to direct practice due to their delayed onset, their excessive danger, or the inability to reproduce them in a practice environment.
} 
discussed, peak oil will include the problems of the 1973 shortages, but the problem will be permanent.

In portraying the problem as one-trial discriminated avoidance responding, it would seem as though research in avoidance learning might be called upon to help understand the problem. ${ }^{3}$ However, avoidance has been studied in both animals and humans on a free-operant or multi-trial basis, in which the subjects get lots of practice. One-trial discriminated avoidance responding involves no practice at all; there is no direct exposure to the contingencies.

\section{The Delay Parameter}

Peak oil is also a problem of delayed aversive consequences: The fact that delayed consequences are less effective than immediate ones is a generic problem in efforts to improve the future (Skinner, 1973). The effects of programs to mitigate peak oil will be realized only after a delay required to implement the programs. In addition, the delayed effects of a mitigation program may precede the peak, further delaying some of the reinforcing consequences of the programs. If peak oil had already clearly occurred, an ensuing crisis would likely motivate an intensive effort to cope with the problem on a scale former President Carter $(1977$, I 8) metaphorically advocated as "the moral equivalent of war." Carter was unable to mobilize support for his campaign of scaling back dependence on oil in part because oil production was decades away from peaking in 1977. Among some of those concerned with the problem of impending peak oil, Carter is seen in retrospect as foresighted in his focus on energy conservation and security (Hartmann, 2005; Koff, 2005).

Delayed events, even very harmful ones, lack concreteness and currency that compels people to pay attention to them, making it difficult even to bring them into the public arena for discussion. In the case of peak oil, both the effects of peak oil and any crash program to address peak oil are delayed future events. Both those who predict peak oil and advocates of a crash program to avoid a harmful peak-oil future will therefore always tend to be judged as incorrect because the aversive future events they predict are nowhere to be seen. Kunstler $(2006$, ๆ 1$)$ referred to a form of this problem when he indicated his critics have taken him to task because "I have so far failed to correctly predict the end of the world."

\footnotetext{
${ }^{3}$ Selected research in avoidance behavior bears some similarities to peak-oil contingencies. In peak oil the aversive consequence is delayed by an unpredictable time interval, is of a relatively long duration, and is likely to fluctuate in intensity. Also, in peak oil the avoidance responses are likely to lessen rather than entirely prevent the aversive consequences. All these features of peakoil contingencies are paralleled in molar studies of avoidance behavior in which avoidance responses do not prevent aversive consequences but instead reduce their delayed rate of occurrence (e.g., Herrnstein \& Hineline, 1966). Studies illustrating that avoidance responding can be successfully maintained by a reduction in the rate of the aversive consequences are free-operant studies in which the subjects receive lots of practice in avoiding recurring consequences, unlike peak-oil contingencies.
} 


\section{The Variability-of-the-Delay Parameter}

As discussed earlier, the length of the delay before the peak is reached is poorly predicted. While some experts specify we are already past the peak point of production, others maintain the peak will not occur for many decades. This lack of consensus also lessens the degree to which information about peak oil functions as an effective motivating operation to induce behavior, like a crash program, that avoids a peak-oil crisis. Deffeyes (2005) has summarized this influence:

In addition to M. King Hubbert's generalized warning, over the last twenty years a dozen different authors predicted that world oil production would peak and start a permanent decline during the 2000-2010 decade. When other experts disagree, the public usually thinks that no valid knowledge exists. The public response becomes, "What, me worry?" (p. 179)

\section{The Aversiveness-Intensity Parameter}

The events that will occur in a post-oil future are to some degree ambiguous, even though there is a broad consensus that peak oil is a harmful event. Some predict anarchy and a breakdown of rule of law (Kunstler, 2005), whereas others entertain notions of a future in which people drive their cars using solar energy, ethanol or hydrogen (e.g., Rifkin, 2002). This lack of consensus concerning the severity of the effects of peak oil lessens the extent to which information about peak oil functions as a conditioned motivating operation (Michael, 2004). An effective motivating operation in this case must include an aversive stimulus, an unpleasant warning signal, but the lack of consensus fails to make the warning sufficiently compelling. In ordinary language, it is more difficult to motivate people to do anything about peak oil because there is significant disagreement about how bad peak oil will be.

Those familiar with energy economics generally realize peak oil will be a serious problem, so the aversiveness-intensity problem mainly applies to those who have not examined the issue. Nonetheless, this currently includes much of the general public, so the aversiveness-intensity parameter is an impediment to bringing the issue to public attention.

\section{The Nature of Avoidance Contingencies}

As discussed earlier, the crash program called for in the Hirsch report is a type of discriminated avoidance response that prevents or postpones an aversive consequence. Avoidance responses do nothing more than maintain the status quo, whereas the failure to emit the avoidance responses enables the aversive consequence. If the crash program were successful, there would be no disastrous consequences. In contrast, failure to make the avoidance response, to carry out the crash program, enables the disaster. Even with practice, avoidance responding is difficult to acquire, partly because nothing immediately happens after the response (Catania, 1998). 
Many avoidance responses are initially acquired as escape responses (Grant \& Evans, 1994; Martin \& Pear, 2003), in which something does happen after the response: the escape response terminates the aversive stimulus. For example, Geller (1992) pointed out that water conservation is often acquired as behavior that escapes the problems of a shortage, whereas recycling is acquired as a response that escapes excess solid waste. Once successfully acquired as escape responses, water conservation and recycling can then function to avoid water shortages and solid-waste excesses. In escape responding, the learner receives practice in removing the aversive stimulus, which appears to facilitate learning how to prevent it as well. However, the nonrecurring nature of peak oil means there is no opportunity to learn to use a crash program to escape the effects of peak oil as a training method to teach subsequent peak-oil avoidance.

If a crash program is not implemented and peaking occurs, the harmful effects of peak oil will then likely activate emergency programs to escape the crisis. These escape responses/programs would have the advantage of being powerfully motivated by emergency conditions, but are likely to result in a rush to use whatever energy sources are available without regard for environmental consequences (Leggett, 2005). In addition, under these emergency conditions there is likely to be a worldwide economic crisis, which will make it difficult even for national governments to fund programs.

If a proactive crash program were pursued, the nature of the discriminated avoidance contingency would likely continue to pose problems. Suppose a national leader were to successfully implement a program that included imposing taxes on fossil fuels, subsidizing solar and wind energy, providing incentives for mass transit and electricpowered vehicles, increasing railway capacity, increasing river-barge traffic, curtailing the subsidization of highways and streets, etc. During the 10 to 20 year interval during which these programs were in effect, critics would likely complain that the programs were largely unnecessary, especially if no major energy problems occurred, which is to say the complaints would be forthcoming even if the programs were achieving their goals. In addition, critics would also likely complain that more immediately pressing problems were being relatively neglected (e.g., unemployment, homelessness, apprehending terrorists, reducing budget deficits, etc.) during the time when a peak-oil future would exist only as an extrapolated abstraction.

Impartial analyses might well correctly indicate the programs were effective in avoiding the worst, but if the programs were successful much of the electorate would see themselves as no better off than before the programs were implemented. Similar circumstances occurred in the case of the Y2K computer problem during the late 1990's: Diligent and relatively expensive avoidance responding prevented the Y2K problem, which led some critics to conclude the problem was originally a hoax that never needed to be addressed (Cascio, 2005).

Discrimination of the avoidance contingency (i.e., identification of the relationship between the crash program and preventing a peak-oil disaster) is likely to grow more probable as time goes on and there are increasing signals that a peak oil crisis is growing closer, but discrimination is most likely in hindsight, after peak oil and its harmful effects have occurred. Simmons (From the Wilderness Publications, 2003, I 12) has come to this 
conclusion based on both the nature of avoidance responding and the difficulty in fixing the date of peak oil:

And crying wolf is bad business unless the wolf turns out to be already at the front door, and by then, the cry is generally too late. And crises are basically problems, by definition, that got ignored. And all great crises were ignored until it became too late to do anything about it. .... Judging the data, for instance, on current decline rates on even fields per basin is very hard to define and it turns out that peaking is one of these fuzzy events that you only know clearly when you see it through a rear view mirror, and by then an alternate resolution is generally too late.

Thomas Hardy (1874/1998) made Simmons' point in Far from the Madding Crowd: "a resolution to avoid an evil is seldom framed till the evil is so far advanced as to make avoidance impossible" (p. 145). In behavioral terms, the effectiveness of motivating operations to induce avoidance behavior often increases over time as current signals of aversive future events become gradually more discriminable. But by the time the motivating operations actually evoke avoidance responding, it is often too late for the avoidance behavior to prevent the aversive consequences.

\section{Additional Challenges in Addressing Peak OIL}

In addition to these basic contingency-related issues in solving the peak-oil crisis are the following challenges: (a) the resistance to change of established patterns of energy use, (b) the history of false signals of oil depletion, (c) the history of technological advancement, and (d) the aversiveness of delivering peak-oil messages.

\section{Resistance to Change}

The use of highly concentrated energy sources such as oil and natural gas has made daily life more reinforcing in many respects and has established routine and stereotypic behaviors that are highly resistant to change (Nevin, 2005). This resistance to change regarding motor vehicle use, for example, occurs even despite lethal and other harmful consequences (Alvord, 2000; Kay, 1997). One quantitative measure of resistance to change is seen in empirical studies of the relative inelasticity of demand for gasoline: Price increases have relatively little impact on short-term gasoline demand (Dahl \& Sterner, 1991; Espey, 1998) and there is some evidence demand inelasticity has increased over the past several decades (Hughes, Knittel, \& Sperling, 2006).

People routinely use motor vehicles to commute long distances, to shop, and to travel even short distances within easy walking range. These behaviors are so well established they occur automatically: People do not routinely consider transportation alternatives but instead engage in stereotyped vehicle-use patterns with the unconscious automaticity associated with contingency-shaped behavior (Skinner, 1969). People who have conducted self-experiments in which they cease vehicle use have observed themselves switch from the automatic nature of contingency-shaped behavior to a verbal 
process in which they logically consider transportation alternatives daily (e.g., Durning, 2006) until new routines are established.

The resistance to change of fossil-fuel use poses a problem for the transition to a peak-oil future because it rigidly frames discussions of what alternatives are acceptable. Existing energy-use practices are accepted as a constant, with everything else subject to change. Proposals like gasoline taxes are seen as politically impossible even among those sympathetic to the problem of energy overconsumption (Quinn, 2006). Verbal behaviors of national leaders and columnists mirror resistance to behavior change. The VicePresident of the United States is quoted as saying that "The American way of life is nonnegotiable" (Cheney, quoted in Powell, 2006, ๆ 17). President George W. Bush (2006, ๆ 45), in his State of the Union address stated "America is addicted to oil," metaphorically comparing oil consumption to the high resistance to change observed in addictive behaviors. However, President Bush proposed no conservation initiatives, but instead advocated the use of technologies to use alternative fuels such as corn-based and cellulosic ethanol, wind, solar, and nuclear power. [President Bush's proposed 2007 budget reduces spending on energy conservation programs (Quinn, 2006).]

Instead of considering fundamental changes in energy use and modes of transportation, discussions tend to be concerned with how to extend existing practices into the future, such as how to power private cars and trucks with alternative fuels (Henderson, 2006; Hopkins, 2006b). In a post-peak oil environment the alternative fuels will likely not be available in sufficient quantities to sustain existing energy-use practices (Heinberg, 2003; Kunstler, 2005) or, like coal, have a range of harmful environmental effects (Leggett, 2005).

The issue of peak oil is typically cast in terms of an energy crisis. The disadvantage of this perspective is that it defines the problem in terms of a lack of abundance of energy sources even though the world's original oil reserves ranged into trillions of barrels. Hubbert, perhaps the first person to contemplate a post-peak oil future, instead portrayed the problem as a culture crisis (Lundberg, 2006a) due to building a society that assumes there will be an endlessly growing supply of fossil fuels. In behavioral terms, the culture crisis is a problem of the resistance to change energy-consumption practices. The inertia inherent in a set of behaviors highly resistant to change is likely to delay portrayal of the underlying problem as a culture crisis rather than an energy crisis.

\section{Prior False Signals of Oil Depletion}

Yergin (2005) points out the current apprehension that oil supplies will begin to decline has been preceded by five previous periods of similar concern, all of which turned out to be misplaced. For example, after Edwin Drake's discovery of oil in 1859, 25 years elapsed during which no oil was discovered anywhere outside of the state of Pennsylvania (Chernow, 1998). This long period of time during which no new discoveries occurred legitimately raised the prospect that petroleum was a relatively scarce commodity. This led one executive of the Standard Oil Company to advocate they abandon the oil business in favor of something with better long-term prospects. 
Additional oil was of course eventually discovered in many places in the U. S. and elsewhere.

Cavallo (2004) depicted this problem of false signals:

The idea that petroleum resources are finite and that petroleum production might peak in the near future seems to have vanished from all discussions of energy policy in Congress, in the press, and even among public interest groups.

This surreal situation is due to several factors. One, certainly, is that pessimists have cried wolf too often. Forecasts of imminent shortages of oil, food, and other natural resources are confounded by the enormous display of material goods that envelops consumers in the West. For most people, the market price of any commodity is what signals shortage or plenty. Time and again, collapsing oil prices have succeeded rising oil prices, leading to the belief that oil will always become cheap again. That oil supplies are currently abundant and inexpensive and have been for nearly 20 years, and that the models used to predict peak oil production are not easy to understand, appear to ignore economic factors, and are based on proprietary data, explain to some degree the present feeling of permanent abundance. (p. 20)

Those individuals who have previously raised concerns about oil depletion were essentially providing false, or at least premature, signals for oil depletion. Those who doubt the imminence of peak oil use this history of false signals as a reason for suggesting that the current indications of peak oil are equally false. From a behavioral perspective, a key effect of presenting a false discriminative stimulus signaling the lack or scarcity of a reinforcer would be to strip the signal of any discriminative control, through extinction, over whatever responding (e.g., conservation, planning for scarcity) would be otherwise occasioned by the discriminative stimulus and any future similar signals.

False signals similarly lose their functional control as conditioned motivating operations though extinction. In ordinary language, people stop listening to predictions that turn out to be false. This effect is maximized due to the repeated presentation of similar stimuli, each time unaccompanied by the consequences they portend. Of course, many people did not experience the previous periods in which the signals for oil depletion were presented, but reading or hearing about them is likely to have the same effect of making the signals less effective through vicarious processes (Bandura, 1969).

The effects of the history of false signals of future disasters should also be understood in a wider context of inaccurate, or at least premature, predictions of other types of doom. For example, Thomas Malthus (1798/1985) incorrectly predicted the human population would grow too large to feed itself by the mid- $19^{\text {th }}$ century. Ehrlich's (1968) more recent predictions of a disaster due to overpopulation have also not been realized. Predictions of worldwide calamity due to computer malfunctions caused by the change in digits from 1999 to 2000 never came to pass, although this was due to diligent avoidance responding with respect to a clearly identifiable event with a specific future date. Nuclear bombings of human populations, widely expected during the 1950's and 1960's, have not occurred since 1945. As a result of incorrect predictions of this sort (or 
correct predictions that have yet to be realized) predictions in general have lost their discriminative and motivational properties. People have come to discount or at least benignly neglect forecasts of future catastrophes, with the exception of recently experienced harmful events like terrorist attacks. This poses a special difficulty for a problem like peak oil, which the Hirsch report indicates will necessarily occur.

\section{Aversive Features of Peak-Oil Messages: Bearers of Bad News}

A problem in spreading information about peak oil is the reluctance of political leaders to bring the problem of peak oil to public attention. The Hirsch report specifies it is necessary to have a 10 to 20 year intensive program to blunt the effects of peak oil, and in order to do this it is necessary to mobilize public support.

Raising the prospect of a less affluent future due to the lack of energy supplies is difficult for politicians and other opinion leaders. Analyses of campaign rhetoric indicate that candidates who deliver upbeat messages promising a bright future are generally more successful than those who raise concerns about the challenges of a difficult future (Zullow, Oettingen, Peterson, \& Seligman, 1988). Politicians who deliver information about aversive events in the future run the risk of establishing themselves as conditioned aversive stimuli by means of classical conditioning, whereas those who deliver promises of a bountiful future establish themselves as conditioned stimuli for positive emotional responses. Conditioning processes that occur in political contexts may work in a manner similar to classical conditioning in advertising (e.g., Shimp, Stuart, \& Engle, 1991; Stuart, Shimp, \& Engle, 1987).

The one major instance in which a major politician attempted to advocate energy conservation and plan for a future of diminished energy was U.S. President Carter, whose efforts in this arena were not successful during his presidency, perhaps dissuading subsequent politicians through vicarious punishment. Because the timing of peak oil is unknown, politicians are reluctant to commit themselves to a plan for energy conservation for fear that they will be seen as a false prophet of a dwindling energy supply, even temporarily.

An important problem in managing the transition to a post-peak-oil future is inducing political leaders to educate and orient the electorate to the necessity of solving the problem in advance of the peak. Politicians who pursue this course run the risk of being perceived negatively, at least in the short run. As with many political issues style is very important and can overcome many of the inherent difficulties of peak oil. For example, Cobb (2005) has called attention to how one politician, Maryland Congressman Roscoe Bartlett, has been able to focus effectively on peak oil and yet project optimism (e.g., Bartlett, 2005). Bartlett, one of a very few North American politicians with a background in science, has founded a congressional peak-oil caucus (Global Public Media, 2005). 


\section{History of Technological Advancement}

Another impediment to motivating people to conserve energy and engage in other activities to prepare for a peak-oil crisis is the advancement in technology throughout human history, especially during the industrial age. Yergin (2005), for example, maintains there is a general historical tendency in history to underestimate the role of technology in oil discoveries. A specific difficulty however is that oil discoveries have been declining since the mid-1960's, despite striking improvements in oil discovery technologies. For example, in mid-2006 the Chevron Corporation successfully drilled an undersea oil well to a record depth of 8.5 kilometers (Chevron, 2006), the latest in a series of improvements since 1965's record depth of 190 meters (Exxon-Mobil, 2006a).

The problem is people have come to expect technology to provide them with relatively inexpensive energy sources (Cavallo, 2004). These expectations are due to a long history of reinforcement in the form of advances in energy and other technologies. With respect to energy-conservation behaviors, technological advances that have provided inexpensive oil supplies have functioned like a source of (practically) responseindependent reinforcement (i.e., getting something for doing little or nothing), weakening incentives to conserve. Current candidates for new energy technologies include cellulosic ethanol, oil shale processing, nuclear fusion, and recovery and processing of methane hydrates. It is unclear at this time whether any commercially significant and environmentally friendly technologies will ever be developed to permit use of these sources. But the mere prospect, however ambiguous, of their potential development reduces the extent to which people are motivated to initiate a crash program in response to peak oil.

\section{Risk MANAGEMENT CONTINGENCIES}

Hirsch et al. (2005) recognized the lack of a clearly predictable fixed date for peak oil and therefore characterized the problem as one of risk management. A risk management approach acknowledges that either the proponents of an early peak (e.g., within 0-20 years) or those of a late peak (e.g., more than 20 years) may be correct, analyzes the consequences of possible correctness and incorrectness, and offers a course of action that produces an optimal combination of the least aversive and the most reinforcing consequences.

Hirsch et al. asked two questions:

1. What are the risks of initiating the crash program prematurely in advance of the peak?

2. What are the risks of initiating the crash program too late in advance of (or after) the peak?

Hirsch and his colleagues maintained the two risks are asymmetric, that with a premature crash program "there might be an unproductive use of resources" (p. 88) whereas a late crash program would result in "a decade or more of devastating economic impacts" (p. 88). In a subsequent interview, Hirsch made the nature of the asymmetry 
clear, underscoring it would be more harmful to initiate the crash program too late rather than too soon (Orkin, 2005). In an appendix to the report, Hirsch et al. suggested further study of the costs and benefits of an early versus a late crash program.

Hirsch et al. (2005) did not identify the specific risks of initiating the program too soon, except to briefly indicate it would entail a potential waste in resources. An appendix to the report however mentions only the risk of repeating the "synthetic fuels experience of the 1970's and 1980's" (p. 91), in which multi-billion dollar expenditures did not result in the manufacture of any cost-effective synthetic fuels (National Environmental Trust, 2001). This particular risk has been muted however because at current oil-price levels the manufacture of synthetic fuels has become cost effective. One such plant will become operational in China during 2007 (Energy Information Administration, 2006a) and planning for another is also underway in Montana (Elliott, 2006).

With other countries and the private sector currently assuming the risks associated with coal-to-liquids plants, it appears the development of synthetic fuels is widely perceived as a future benefit rather than a risk, at least in terms of dollar costs and benefits. Coal-to-liquids conversions nonetheless have serious drawbacks. A Chinese official recently criticized these conversions as both an energy-inefficient process and a source of high carbon dioxide emissions (Biopact, 2006). Coal-to-liquids conversions have significant environmental risks, but at current oil prices these appear not to be the same problems of the synthetic fuel experience of the earlier era.

Many energy conservation programs would not carry much risk in the case of a late peak and would have important benefits. The Hirsch report identified improvements in vehicle fuel economy as a part of the mitigation program. However, if such improvements were required by the government even 30 to 50 years or longer before peaking, these improvements would likely not be a severe drain on resources and would have direct benefits on reducing $\mathrm{CO}_{2}$ emissions, global warming and various forms of environmental pollution (Union of Concerned Scientists, 2005). Similarly, increased use of mass transit would share the benefits of improved fuel economy, reduce vehicle fatalities and injuries and permit elimination of a significant portion of the annual multibillion dollar government subsidies required to maintain streets and highways for private cars (Alvord, 2000; Kay, 1997; Nevin, 2005). Increased use of distance education would have similar benefits (Roy, Potter, Yarrow, \& Smith, 2005). Simmons (2006) has advocated increased use of telecommuting, a transition from long-distance trucking to rail and barge transport, and eating locally-grown food, each of which would also have desirable environmental benefits even if they were timed too early in advance of peak oil.

Early initiation of a crash program to counter the effects of peak oil would also have additional benefits in many Western countries that rely on foreign sources of oil that endanger their security. This is a concern both because these oil sources are precarious and because payments for these sources finance terrorism (Institute for the Analysis of Global Security, 2006). Former CIA Director R. James Woolsey, Former National Security Advisor Robert McFarlane and former Senator Tom Daschle for example are among several bipartisan sponsors of the "Set America Free" coalition (Set America 
Free, 2006) that seeks to reduce dependence on foreign oil through conservation and development of alternative fuels. As represented by the aims and purposes of this coalition, for example, there is at least a partial convergence of interests among environmentalists, those concerned with national security, and those striving to avoid the damaging economic effects of peak oil.

As discussed in connection with the nature of avoidance contingencies, initiation of an early (or even an on-time) crash program is likely to entail more political risk prior to the oil peak than waiting until the peak is more apparent. Currently, for example, advocates of peak oil are criticized whereas those who are silent on the issue remain safe from criticism and controversy. However, once the oil peak arrives, especially in the absence of an ongoing crash program, the tables will be turned. Citizens of many countries are likely to be outraged because their leaders did not warn them in advance of the problem. The behavioral problem is that the political risk (i.e., aversive consequences) for peak-oil advocacy occurs immediately; whereas the political risk for silence or denial of the issue is delayed until the peak itself. These contingencies therefore demand foresighted leadership. As Judis $(2006, \boldsymbol{q} 10)$ observed:

If America is to deal with the possibility of peak oil--or for that matter, with its sister problem of global warming--our leaders are going to have to take political risks. Bush began the discussion by alluding to America's addiction to oil, but others will have to continue it.

Unfortunately, at this time the problem of peak oil is not conceptualized in terms of risk management. Instead, discussions of the issue are typically framed in terms of who is "right" and "wrong" regarding the imminence of peak oil. This mode of conceptualizing the issue, along with the problem of resistance to change, has led to placing an implicit high-stakes bet on the behavioral alternative that carries the maximum risk, which is our current course of inaction on peak oil. Right/wrong discussions are relatively unproductive in comparison to a risk management exercise that minimizes the possibility of encountering the worst consequences, adds additional environmental benefits and leaves us free to adapt to a sustainable future beyond peak oil.

\section{FINAL NOTES}

Many of the considerations I have discussed support Simmons' (From the Wilderness Publications, 2003) and Leggett's (2005) conclusion that no advance program of mitigation is likely to be implemented prior to the time when oil peaks. However, understanding the nature of the contingencies and other conditions that work against a timely mitigation program is itself part of an ultimate solution. Calling attention to the severity of a looming problem that is currently ignored can function to some degree as a motivating operation to solve the problem. Understanding cultural and contingencyrelated vulnerabilities can motivate the planning and development of alternative programs, Plan B's, even if these programs must be carried out late, after the oil peak is reached. As Simmons (2005b) has indicated, there is currently no Plan B, no plan for an 
unanticipated future in which oil peaks and becomes a scarce commodity. This alternative planning will necessarily be a large-scale enterprise, yet should take place on both a personal (Power Switch, 2006) and local level (Nevin, 2005), as well as on the governmental and other institutional levels emphasized in the Hirsch report.

Behavior analysis can play a role in providing Plan B solutions, for example by drawing on and revitalizing environmental and energy-conservation research and application (Lehman \& Geller, 2004). Specific solutions include encouraging the use of mass transit, supporting the development of communities that are friendly to walkers and bicyclists, reducing the subsidies for private motor vehicle use, consuming locally grown foods, encouraging energy-efficient forms of rail and barge cargo transportation, and promoting the use of distance education and telecommuting. In a future beyond peak-oil, research and application in these areas will be increasingly essential to meeting unprecedented challenges.

\section{REFERENCES}

Alavosius, M. P., \& Sulzer-Azaroff, B. (1990). Acquisition and maintenance of health-care routines as a function of feedback density. Journal of Applied Behavior Analysis, 23, 151162. http://dx.doi.org/10.1901/jaba.1990.23-151

Alvord, K. (2000). Divorce your car!: Ending the love affair with the automobile. Gabriola Island, British Columbia, Canada: New Society Publishers.

Andrews, S. (2006). Prominent CERA official - "Peak Oil theory is garbage". Retrieved October 30, 2006 from http://www.energybulletin.net/20418.html

Bandura, A. (1969). Principles of behavior modification. New York: Holt, Rinehart \& Winston.

Bartlett, R. (2005). April 20, 2005 Special order speech: Our dependence on foreign oil. Retrieved October 21, 2006 from the Web site of U. S. Representative Roscoe Bartlett: http://www.bartlett.house.gov/UploadedFiles/energyspeech4-20-05.pdf

Biopact. (2006). Chinese top official dismisses coal-to-liquids as irresponsible and inefficient. Retrieved October 27, 2006 from http://biopact.com/2006/10/chinese-top-official-dismissescoal-to.html

Blanchard, R. D. (2005). The future of global oil production: Facts, figures, trends and projections, by region. Jefferson, NC: McFarland \& Co.

Bloomberg. (2006). Meeting 'peak-oil threat' will cost \$20 trillion. Retrieved September 21, 2006 from http://www.peakoil.com/article19116.html

Brown, E., \& Jacobson, M. F. (2005). Cruel oil: How palm oil harms health, rainforest \& wildlife. Washington, DC: Center for Science in the Public Interest. Retrieved February 16, 2007 from http://www.cspinet.org/palm/PalmOilReport.pdf

Brown, L. R. (2007). Distillery demand for grain to fuel cars vastly understated: World may be facing highest grain prices in history. Retrieved February 12, 2007 from http://www.earthpolicy.org/Updates/2007/Update63.htm

Bush, G. W. (2006). State of the union address by the president. Retrieved October 19, 2006 from the White House Web site: http://www.whitehouse.gov/stateoftheunion/2006/index.html

Campbell, C. J. (1988). The coming oil crisis. Brentwood, Essex, England: Multi-Science Publishing.

Campbell, C. J. \& Laherrère, J. H. (1998). The end of cheap oil. Scientific American, 278, 78-83. http://dx.doi.org/10.1038/scientificamerican0398-78 


\section{GRANT}

Carter, J. (1977). The President's proposed energy policy. Retrieved February 22, 2007 from http://www.pbs.org/wgbh/amex/carter/filmmore/ps energy.html

Cascio, J. (2005). Peak oil and the curse of Cassandra. Retrieved February 5, 2007 from http://www.worldchanging.com/archives/003224.html

Catania, A. C. (1998). Learning (4 ${ }^{\text {th }}$ ed.). Upper Saddle River, NJ: Prentice-Hall.

Catton, W. (1982). Overshoot: The ecological basis of revolutionary change. Urbana, IL: University of Illinois Press.

Cavallo, A. (2004). Oil: The illusion of plenty. Bulletin of the Atomic Scientists, 60, 20-22, 70. Retrieved October 29, 2006 from http://www.thebulletin.org/article.php?art ofn=jf04cavallo

Chernow, R. (1998). Titan: The life of John D. Rockefeller, Sr. New York: Random House.

Chevron. (2006). Chevron announces record setting well test at Jack. Retrieved October 6, 2006 from http://www.chevron.com/news/press/2006/2006-09-05.asp

Clinton, W. J. (2006). Speech: The opportunity for private citizens to effect positive change in an increasingly interdependent world. Retrieved October 30, 2006 from the Clinton Foundation Web site: http://www.clintonfoundation.org/032806-sp-cf-gn-gl-gbr-sp-the-opportunity-forprivate-citizens-to-effect-positive-change-in-an-increasingly-interdependent-world.htm

Cobb, K. (2005). Trying to be optimistic about peak oil. Retrieved October 21, 2006 from http://resourceinsights.blogspot.com/2005/04/trying-to-be-optimistic-about-imminent.html

Cohen, D. (2007). Palm oil: The Southeast Asia report. Retrieved February 12, 2007 from http://www.theoildrum.com/node/2214

Córdova, E. (1996). The situation of Cuban workers during the "special period in peacetime". Proceedings of the Fifth Annual Meeting of the Association for the Study of the Cuban Economy (ASCE), Miami, FL, August 1996. Retrieved from the University of Texas Web site: http://lanic.utexas.edu/la/cb/cuba/asce/cuba6/45Cordova.fm.pdf

Crensen, M. (2005). Experts: Petroleum may be nearing peak. Retrieved November 1, 2006 from http://www.commondreams.org/headlines05/0528-03.htm

Dahl, C., \& Sterner, T. (1991). Analyzing gasoline demand elasticities: A survey. Energy Economics, 3, 203-210. http://dx.doi.org/10.1016/0140-9883(91)90021-Q

Deffeyes, K. S. (2005). Beyond oil: The view from Hubbert's peak. New York: Farrar, Straus and Giroux.

Deffeyes, K. S. (2006). Estimate of uncertainty. Retrieved October 20, 2006, from the Web site of Princeton University: http://www.princeton.edu/hubbert/current-events.html

Durning, A. (2006). The first law of car-lessness, \#16. Retrieved October 29, 2006 from http://www.sightline.org/daily score/archive/2006/09/05/the-first-law-of-car-lessness-16

Elliott, S. (2006). Governor and companies announce agreement to build CTL facility in Montana. Retrieved October 25, 2006 from the Web site of the State of Montana: http://governor.mt.gov/news/pr.asp?ID=387

Energy Bulletin. (2006a). Al Gore: We're at or near peak oil. Retrieved October 30, 2006 from http://www.energybulletin.net/17142.html

Energy Bulletin (2006b). Peak oil primer and links. Retrieved July 21, 2006 from http://www.energybulletin.net/primer.php

Energy Information Administration (2006a). International energy outlook. Retrieved October 25, 2006 from http://www.eia.doe.gov/oiaf/ieo/coal.html

Energy Information Administration (2006b). U.S. crude oil field production (thousand barrels) (annual table). Retrieved June 21, 2006 from http://tonto.eia.doe.gov/dnav/pet/hist/morfpus1A.htm

Ehrlich, P. R. (1968). The population bomb. New York: Ballantine Books. 


\section{Peak Oil as a Behavioral Problem}

Espey, M. (1998). Gasoline demand revisited: An international meta-analysis of elasticities. Energy Economics, 20, 273-295. http://dx.doi.org/10.1016/S0140-9883(97)00013-3

Esser, R. (2005). The oil industry growth challenge: Expanding production capacity. Prepared testimony to the U.S. House of Representatives Energy and Air Quality Subcommittee, December 7, 2005. Retrieved October 26, 2006 from http://www.cera.com/aspx/cda/public1/news/articles/newsArticleDetails.aspx?CID=7777

Exxon-Mobil. (2006a). Exxon-Mobil deepwater solutions. Retrieved October 6, 2006 from http://www.exxonmobil.com/Corporate/Newsroom/Publications/deepwater/drilling/mn_drilli ng.html

Exxon-Mobil. (2006b). Peak oil? Contrary to the theory, oil production shows no sign of a peak. Advertisement retrieved September 26, 2006 from http://www.exxonmobil.com/Corporate/Files/Corporate/OpEd_peakoil.pdf

From the Wilderness Publications. (2003). Revealing statements from a Bush insider about peak oil and natural gas depletion. Retrieved October 29th, 2006 from http://www.fromthewilderness.com/cgibin/MasterPFP.cgi?doc=http://www.fromthewilderness.com/free/ww3/061203 simmons.htm 1

Geller, E. S. (1992). It takes more than information to save energy. American Psychologist, 47, 814-815. http://dx.doi.org/10.1037/0003-066X.47.6.814

Glenn, S. S. (1991). Contingencies and metacontingencies: Relations among behavior, cultural, and biological evolution. In P. A. Lamal (Ed.), Behavioral analysis of societies and cultural practices (pp. 39-73). New York: Hemisphere Publishing.

Global Public Media. (2005). Peak oil resolution in the U. S. House of Representatives. Retrieved November 1, 2006 from http://www.globalpublicmedia.com/articles/572

Goodstein, D. (2004). Out of gas : The end of the age of oil. New York: W. W. Norton.

Grant, L. K., \& Evans, A. (1994). Principles of behavior analysis. New York: Harper-Collins.

Hardy, T. (1998). Far from the madding crowd. New York: Doubleday. (Original work published 1874).

Hartmann, T. (2005). Carter tried to stop Bush's energy disasters-28 Years Ago. Retrieved November 4, 2006 from http://www.commondreams.org/views05/0503-22.htm

Heinberg, R. (2003). The party's over: Oil, war and the fate of industrial societies. Gabriola Island, BC, Canada: New Society Publishers.

Heinberg, R. (2004). Powerdown: Options and actions for a post-carbon world. Gabriola Island, BC, Canada: New Society Publishers.

Henderson, B. (2006). Pragmatists and heretics-Peak oil and runaway global warming. Retrieved October 30, 2006 from http://www.countercurrents.org/po-henderson180906.htm

Herrnstein, R. J., \& Hineline, P. N. (1966). Negative reinforcement as shock-frequency reduction. Journal of the Experimental Analysis of Behavior, 9, 421-430. http://dx.doi.org/10.1901/jeab.1966.9-421

Hirsch, R. L., Bezdek, R., \& Wendling, R. (2005). Peaking of world oil production: Impacts, mitigation, \& risk management. Retrieved June 28, 2006 from the United States Department of Energy Web site: http://www.netl.doe.gov/publications/others/pdf/Oil_Peaking_NETL.pdf

Hopkins, R. (2006a). ASPO 5. Robert Hirsch scares me out of my wits. Retrieved October 20, 2006 from http://www.transitionculture.org/?p=414

Hopkins, R. (2006b). ASPO 5 - The two distinct paradigms within the peak oil movement. Retrieved October 30, 2006 from http://transitionculture.org/?p=406 


\section{GRANT}

Howard, J. L. (2006). Printed media coverage of 'peak oil': A crude statistical review. Retrieved October 22, 2006 from http://www.powerswitch.org.uk/portal/images/stories/papers/poitmacsr.pdf

Hughes, J. D. (2006). Natural gas in North America: Should we be worried? Presentation to the World Oil Conference, ASPO - USA, Boston, MA. Retrieved from http://www.aspousa.com/fall2006/presentations/pdf/Hughes_D NatGas Boston 2006.pdf

Hughes, J. E., Knittel, C. R., \& Sperling, D. (2006). Evidence of a shift in the short-run price elasticity of gasoline demand. Retrieved September 19, 2006 from the University of California at Davis Economics Department Web site: http://www.econ.ucdavis.edu/faculty/knittel/papers/gas demand 083006.pdf

Institute for the Analysis of Global Security. (2006). Fueling terror. Retrieved October 22, 2006, from http://www.iags.org/fuelingterror.html

Institute of Science in Society. (2006). Biofuels for oil addicts: Cure worse than the addiction. Retrieved February 12, 2007 from http://www.i-sis.org.uk/BFOA.php

Judis, J. B. (2006). Bush and peak oil: Oil crisis. Retrieved October 28, 2006 from The New Republic Online Web site: http://www.tnr.com/doc.mhtml?i=w060213\&s=judis021406

Kay, J. H. (1997). Asphalt nation: How the automobile took over America and how we can take it back. Berkeley: University of California Press.

Klare, M. T. (2004). Blood and oil: The dangers and consequences of America's growing dependency on imported petroleum. New York: Metropolitan Books.

Koff, S. (2005). Was Jimmy Carter right? Retrieved November 4, 2006 from http://www.energybulletin.net/9657.html

Kunstler, J. H. (2005). The long emergency: Surviving the converging catastrophes of the twentyfirst century. New York: Atlantic Monthly Press.

Kunstler, J. H. (2006). The twang factor. Retrieved October 20, 2006 from http://www.energybulletin.net/18022.html

Leggett, J. (2005). The empty tank: Oil, gas, hot air, and the coming global financial catastrophe. New York: Random House.

Leggett, J. (2006). What they don't want you to know about the coming oil crisis. Retrieved February 16, 2007 from http://www.energybulletin.net/12226.html

Lehman, P. K., \& Geller, E. S. (2004). Behavior analysis and environmental protection: Accomplishments and potential for more. Behavior and Social Issues, 13, 13-32. http://dx.doi.org/10.5210/bsi.v13i1.33

Lundberg, J. (2006a). (How can we already be) looking at the end of the age of oil and abundant energy. Retrieved October 21, 2006 from

http://www.culturechange.org/cms/index.php?option=com_content\&task=view\&id=75\&Ite $\operatorname{mid}=1$

Lundberg, J. (2006b). Peak oil naysayers partying on for growth. Retrieved October 18, 2006 from http://www.culturechange.org/cms/index.php?option=com_content\&task=view\&id=76\&Ite mid=1

Malthus, T. R. (1985). An essay on the principle of population. New York: Penguin. (Original work published 1798).

Mattaini, M. A. (2006). Will cultural analysis become a science? Behavior and Social Issues, 15, 68-80. http://dx.doi.org/10.5210/bsi.v15i1.380

Martin, G., \& Pear J. (2003). Behavior modification: What it is and how to do it ( $7^{\text {th }}$ ed.). Upper Saddle River, NJ: Prentice-Hall. 


\section{Peak Oil as a Behavioral Problem}

Maxwell, C. T. (2004). The gathering storm. Retrieved October 26, 2006 from http://www.energybulletin.net/3161.html

McBay, A. (2005). A community solution to peak oil: An interview with Megan Quinn. Retrieved July 5, 2006 from http://www.energybulletin.net/5721.html

Michael, J. (2004). Concepts and principles of behavior analysis. Kalamazoo, MI: Association for Behavior Analysis.

Motavalli, J. (2005). Matthew R. Simmons: A diminished future for Saudi oil. Emagazine.com, 16. Retrieved October 20, 2006 from http://www.emagazine.com/view/?2574

National Environmental Trust. (2001). America, oil \& national security 2002: What government and industry data really show. Retrieved November 1, 2006 from http://www.net.org/security/america oil.pdf

Nevin, J. (2005). The inertia of affluence. Behavior and Social Issues, 14, 7-20. http://dx.doi.org/10.5210/bsi.v14i1.118

Orkin, J. (2005). Avoiding the question - the continuing peak oil production debate. An interview with Robert Hirsch, author of peak oil report for U.S. Department of Energy. Retrieved October 5, 2006 from http://www.threemonkeysonline.com/threemon_article_peak_oil_production_us_energy_dep artment_robert_hirsch.htm

Pfeiffer, D.A. (2004). Global climate change \& peak oil (Part III). Retrieved October 6, 2006 from http://www.fromthewilderness.com/free/ww3/072004_global_climate3.shtml

Phillips, K. (2006). American theocracy: The peril and politics of radical religion, oil, and borrowed money in the $21^{\text {st }}$ century. New York: Viking.

Powell, A. (2006). A tour of human history, with guide Jared Diamond: Pulitzer-winning author delivers Prather Lectures. Retrieved October 19, 2006 from http://www.news.harvard.edu/gazette/2006/03.16/05-diamond.html

PowerSwitch. (2006). Personal energy descent plan. Retrieved October 21, 2006 from http://www.powerswitch.org.uk/portal/images/stories/leaflets/personalenergydescentplan.pdf

Quinn, J. B. (2006). What need is policy: We are swilling oil faster than new fields are being discovered. Retrieved October 19, 2006 from http://www.msnbc.msn.com/id/13773313/site/newsweek/

Quinn, M. (2004). The power of community: How Cuba survived peak oil. Retrieved July 5, 2006 from http://www.globalpublicmedia.com/articles/657

Rifkin, J. (2002). The hydrogen economy : The creation of the worldwide energy web and the redistribution of power on earth. New York: Tarcher/Putnam, 2002.

Roy, R., Potter, S., Yarrow, K., \& Smith, M. (2005). Towards sustainable higher education: Environmental impacts of campus-based and distance higher education systems. Retrieved February 5, 2007 from the Web site of the Open University: http://www3.open.ac.uk/events/3/2005331_47403_01.pdf

Semb, G. (1974). The effects of mastery criteria and assignment length on college student test performance. Journal of Applied Behavior Analysis, 7, 61-71.

http://dx.doi.org/10.1901/jaba.1974.7-61

Semple, R. B. Jr. (2006). The end of oil. Retrieved October 20, 2006 from http://www.energybulletin.net/13368.html

Set America Free. (2006). Who we are. Retrieved October 30, 2006 from http://www.setamericafree.org/who.htm 
Shimp, T. A., Stuart, E. W., \& Engle, R. W. (1991). A program of classical conditioning experiments testing variations in the conditioned stimulus and context. Journal of Consumer Research, 18, 1-12. http://dx.doi.org/10.1086/209236

Simmons, M. R. (2005a). Depletion and peak oil: A serious issue or an over exaggerated fear? Presentation to the American Meterological Society, July 25, 2005. Retrieved October 20, 2006 from http://www.simmonsco-intl.com/files/Capitol\%20Hill\%20\%20Depletion\%20\&\%20Peak\%20oil.pdf

Simmons, M. R. (2005b). Twilight in the desert: The coming Saudi oil shock and the world economy. Hoboken, NJ: John Wiley \& Sons.

Simmons, M. R. (2006). Summer's over: Preparing for a winter of discontent. Presentation to the Houston Bar Association, September 12, 2006. Retrieved October 24, 2006 from http://www.simmonsco-intl.com/files/Houston\%20Bar\%20Association\%20BW.pdf

Skrebowski, C. (2006). Peak oil - the emerging reality. Presentation to the Fifth International ASPO Conference, San, Rossore, Italy. Retrieved September 19, 2006 from http://www.aspoitalia.net/images/stories/aspo5presentations/Skrebowsky_ASPO5.pdf

Skinner, B. F. (1969). Contingencies of reinforcement: A theoretical analysis. New York: Appleton Century Crofts.

Skinner, B. F. (1973). Are we free to have a future? Impact, 3, 5-12.

Stuart, E. W., Shimp, T. A., \& Engle, R. W. (1987). Classical conditioning of consumer attitudes: Four experiments in an advertising context. Journal of Consumer Research, 14, 334-349. http://dx.doi.org/10.1086/209117

Sulzbacher, S.I., \& Houser J. E. (1968). A tactic to eliminate disruptive behaviors in the classroom: group contingent consequences. American Journal of Mental Deficiency, 73, 88-90.

Tertzakian, P. (2006). A thousand barrels a second: The coming oil break point and the challenges facing an energy dependent world. New York: McGraw-Hill.

U. S. Census Bureau. (2006a). Historical estimates of world population. Retrieved November 3, 2006 from the U. S. Census Bureau Web site:

http://www.census.gov/ipc/www/worldhis.html

U. S. Census Bureau. (2006b). Total midyear population for the world: 1950-2050. Retrieved November 3, 2006 from the U. S. Census Bureau Web site: http://www.census.gov/ipc/www/worldpop.html

Union of Concerned Scientists. (2005). Questions and answers on fuel economy. Retrieved October 30, 2006 from http://www.ucsusa.org/clean_vehicles/fuel_economy/questionsandanswers-on-fuel-economy.html

Ward, S. (2006). Oil prices: A pause, then up. Interview with Charles Maxwell, Senior Oil Analyst, Weeden \& Co. Barron’s, 86(42), 42-43.

Wood, T. (2005). Oil doomsday is nigh, tar sands not a substitute. Retrieved July 10, 2006 from http://www.resourceinvestor.com/pebble.asp?relid=9692 
Yergin, D. (2005). It's not the end of the oil age. Technology and higher prices drive a supply buildup. Retrieved online July 6, 2006 from the Web site of the Washington Post: http://www.washingtonpost.com/wpdyn/content/article/2005/07/29/AR2005072901672 .html

Zullow, H., Oettingen, G., Peterson, C., \& Seligman, M. E. P. (1988). Explanatory style and pessimism in the historical record: CAVing LBJ, Presidential Candidates, and East versus West Berlin. American Psychologist, 43, 673-682.

http://dx.doi.org/10.1037/0003-066X.43.9.673 